\title{
Epigenetics of oral and oropharyngeal cancers (Review)
}

\author{
DANIELA RUSSO $^{1 *}$, FRANCESCO MEROLLA ${ }^{2 *}$, SILVIA VARRICCHIO ${ }^{1}$, GIOVANNI SALZANO $^{3}$, \\ GIOVANNI ZARRILLI $^{2}$, MASSIMO MASCOLO ${ }^{1}$, VIVIANA STRAZZULLO ${ }^{1}$, \\ ROSA MARIA DI CRESCENZO ${ }^{1}$, ANGELA CELETTI ${ }^{4}$ and GENNARO ILARDI ${ }^{1}$
}

\footnotetext{
${ }^{1}$ Department of Advanced Biomedical Sciences, Pathology Unit, University of Naples Federico II, I-80131 Naples;

${ }^{2}$ Department of Medicine and Health Sciences V. Tiberio, University of Molise, I-86100 Campobasso; ${ }^{3}$ Department of Neuroscience and Reproductive and Odontostomatological Sciences, Operative Unit of Maxillofacial Surgery, University of Naples Federico II, I-80131 Naples; ${ }^{4}$ Institute for Experimental Endocrinology and Oncology

Gaetano Salvatore, Italian National Council of Research, I-80131 Naples, Italy
}

Received March 6, 2018; Accepted June 20, 2018

DOI: $10.3892 / b r .2018 .1136$

\begin{abstract}
Oral and oropharyngeal cancers represent the two most common malignancies of the head and neck region. The major risk factors for these cancers include alcohol consumption, tobacco use (via smoking or chewing) and high-risk human papillomavirus infection. The transition from normal epithelium to premalignant tissue and finally carcinoma is in part caused by a summation of genetic and epigenetic modifications. Epigenetic refers to modifications in the way the genome is expressed in cells. The most common examples of epigenetic control of gene expression are DNA methylation, histone modification and regulation by small non-coding RNAs. The aim of the current paper was to review the recent studies on the main epigenetic changes that have been suggested to serve a role in the carcinogenesis process and progression of oral and oropharyngeal cancers. Furthermore, it is discussed how the epigenetic changes may be used as potential predictive biomarkers and how recent findings in the field may impact the personalized cancer therapy approach for these tumors.
\end{abstract}

\section{Contents}

1. Introduction

2. OSCC and OPSCC carcinogenesis

3. Epigenetics

4. Saliva-detectable hypermethylation

Correspondence to: Dr Gennaro Ilardi, Department of Advanced Biomedical Sciences, Pathology Unit, University of Naples Federico II, Via Serio Pansini 5, I-80131 Naples, Italy

E-mail: gennaro.ilardi@gmail.com

*Contributed equally

Key words: epigenetics, oral squamous cell carcinoma, oropharyngeal squamous cell carcinoma, human papillomavirus
5. miRNA

6. Therapeutic implications

7. Conclusions

\section{Introduction}

Oral and oropharyngeal cancers are the most common malignancies of the head and neck region, with squamous cell carcinoma being the most common histotype $(1,2)$. Reportedly, $\sim 300,000$ new cases of oral cancers are diagnosed worldwide annually, of which $\sim 140,000$ are oropharyngeal cancers, with a male: female ratio that varies between $2: 1$ and 4:1 (3). Oral squamous cell carcinoma (OSCC) and oropharyngeal squamous-cell carcinoma (OPSCC) are often listed together and, accounted as a single entity, represent the sixth most common malignancy worldwide (4-6).

Knowledge of these cancers has improved substantially over recent decades, but the therapeutic outcome has remained mostly unchanged, with a five year survival rate of $~ 50 \%$ (7). The more advanced the stage of cancer at diagnosis, the lower the response rate to therapy; furthermore, patients diagnosed with high stage OSCC or OPSCC have a high risk of developing metastases (both lymph node and distant) and relapses (7).

Oral carcinogenesis is caused by environmental and endogenous factors; categorized in the first group are regular tobacco and alcohol use and persistent high-risk human papillomavirus (HPV) infection. HPV-related OPSCC constitutes a different biological entity compared with HPV-negative cases (8). In particular, HPV-related OPSCC differs significantly in epidemiology from HPV-negative cases and those of the oral cavity: HPV-negative head and neck squamous cell carcinoma (HNSCC) mostly affects individuals of more than 60 years in age, and its incidence is decreasing; conversely, the incidence of HPV-positive HNSCC is increasing, and is often diagnosed in young adults $(9,10)$. HPV status also significantly impacts on prognosis; namely, HPV-positive OPSCC is associated with better prognosis when compared with HPV-negative cases and $\operatorname{OSCC}(9,11)$.

Endogenous factors are generally linked to genetic and epigenetic alterations. Genetic alterations refer to changes 
in the DNA sequence including deletions, amplifications and mutations; these changes are not reversible. Epigenetic alterations are a group of heritable modifications in DNA expression that manifest without direct DNA modification. In the present review, the main epigenetic alterations described recently in the literature on oral and oropharyngeal cancers are discussed.

\section{OSCC and OPSCC carcinogenesis}

'Field cancerization' (also known as the field effect), is a concept first introduced by Slaughter et al (12) in 1953 for oral cancers. They described field cancerization as being a process in which an area of epithelium has been preconditioned by an, at that time, unknown carcinogenic agent, enabling epidermoid carcinoma of the oral stratified squamous epithelium to originate. Some of the carcinogenic agents involved in neoplastic transformation of oral epithelium have been established, among which tobacco and alcohol are considered as principal risk factors; however, the mechanisms of field cancerization in HPV-related HNSCC remain unknown (9). Tobacco and alcohol seem to cause an anaplastic transformation that involves an area or 'field' of mucosa rather than single cells (13). This would explain the tendency of OSCC and OPSCC to recur (10-30\% of cases) in different areas relative to the original location, even following surgical removal with tumor free margins (13).

Aside from in HNSCC, the field effect has been also described for cancers of other anatomical regions, including the esophagus (14), colon (15), urinary tract (16), skin (17), breast (18), uterine cervix (19) and airway epithelium (20).

HPV-related carcinogenesis. HPV is an established causative factor in $25 \%$ of global cases of HNSCCs. The oropharynx is the anatomical location in which HPV-related cancers are more frequently observed; they amount to $\sim 36 \%$ of the total, $\sim 87 \%$ of which are related to HPV 16. In the oral cavity, $\sim 23 \%$ of cancers are HPV-related, $\sim 69 \%$ of which are HPV 16-related.HPV 18 is the second most common papilloma virus type in HNSCC, amounting for $\sim 8 \%$ of OSCCs and $\sim 1 \%$ of OPSCCs (21). Certain locations appear to have higher HPV-related cancer incidence: For instance, tonsil and base of the tongue cancers have been identified to be HPV-linked in $50-80 \%$ of cases (22-24).

E6 and E7 are considered the most important HPV proteins involved in carcinogenesis; E6 protein has several functions, with a key and well-established function being to induce the degradation of $\mathrm{p} 53$, a widely studied oncosuppressor (25-27). E6 binds the ubiquitin-protein ligase, E6AP; the E6/E6AP heterodimer can then bind $\mathrm{p} 53$, which is ubiquitinated and degraded in proteasomes $(26,27)$.

E7 binds retinoblastoma protein $(\mathrm{pRb})$. The main function of $\mathrm{pRb}$ is to negatively regulate several transcriptional factors, including E2F1-3 (25). When E7 binds pRb, E2F transcriptional factors are no longer inhibited, and have the possibility to activate the transcription of cell cycle-related genes, including cyclin A and cyclin E (25).

Several biomarker expression studies performed in HPV-positive OPSCC have established a clear distinction between HPV-active and HPV-inactive cancers (28-34). HPV-active tumors contain and express HPV sequences, are positive for p16 immunohistochemistry as well as for HPV RNA (35) and exhibit gene expression profiles that suggest a 'HPV signature', dominated by changes in genes that control the cell cycle, proliferation and mitosis (36). Numerous differences have been described in gene expression profiles between HPV-active and HPV-negative cancers, the latter being dominated by changes in genes that control cell motility, angiogenesis and epithelial-mesenchymal transition, associated with aggressive clinical behavior (36). The gene expression profiles of HPV-inactive tumors lack the characteristic 'HPV signature' and are notably more similar to HPV-negative tumors, although some differences can be detected, the clinical significance of which remains to be determined $(36,37)$.

Tomar et al (37), proposed that HPV-inactive cancers may originate as HPV-active lesions that progressively become independent of E6/E7 for proliferation and tumorigenic potential. Methylation mechanisms have been demonstrated as responsible for the silencing of HPV sequences in cells that have acquired mutations that may 'replace' E6/E7 function (38). HPV methylation has been investigated in a variety of cancers and cancer cell lines (38); however, the role of HPV methylation and other mechanisms leading to a possible progression from HPV-dependence to HPV-independence in head and neck cancer remains to be determined $(37,39)$.

Tobacco-related carcinogenesis. Tobacco consumption is among the most important risk factors in numerous cancers. Expectedly, it has been widely demonstrated that tobacco consumption is a major risk factor for OSCC and OPSCC $(40,41)$.

Among smoker patients, the risk for the development of oral cancer is greater than three times higher than in non-smokers; for pharyngeal cancers the risk becomes greater than six times higher for smokers (42). The risk of oral and oropharyngeal cancers returns to baseline when smoking is stopped for at least 20 years (43).

Additionally, smokeless tobacco is established as an independent risk factor for oral cancer; an increased risk of oral cancer has been identified with use of numerous tobacco products, including gutka, supari (areca nut) and betel quid (Piper betle), with an odds ratio between 5.1 and 11.4 (44).

Alcohol-related carcinogenesis. Ethanol serves as a risk factor for the development of oral cancer through its local and systemic effects. By its local effects, alcohol may increase the permeability of the mucosa by dissolving the lipid component of the epithelium; it may provide indirect cellular damage through acetaldehyde; it may amplify the toxicity of other carcinogenic agents; and it may cause hyposalivation, leading to a higher exposition to locally acting carcinogens.

As systemic effects, ethanol acts to reduce first pass hepatic metabolism of toxic substances; it may lead to immunosuppression; and it may be associated with malnutrition, which can enhance the risk of developing cancer (45).

Patients who stop drinking exhibit a decreased risk of developing OSCC and OPSCC over time; however, for oropharyngeal cancer, the risk does not return to baseline, remaining higher than in those without a history of alcohol consumption. Otherwise, for oral cancer, the risk in former 
drinkers after more than 20 years is reportedly lower than in the 'never drinker' population (43).

EBV-related carcinogenesis. Epstein-Barr virus (EBV) was identified in 1964 by Epstein et al (46), in a Burkitt lymphoma-derived cell line. It is a herpesvirus (HHV-4), and therefore its genome is composed of DNA (47). EBV is the etiologic agent of mononucleosis, also known as the kissing disease for its transmission path; this is a self-limiting disease, after which the virus may remain latent, with infected individuals potentially becoming lifelong carriers of the virus (48). Worldwide, more than $90 \%$ of adults infected with EBV exhibit no sign of the infection (47).

EBV is established as a causative factor in numerous cancers, including Burkitt lymphoma, Hodgkin lymphoma, immunosuppression-related non-Hodgkin lymphoma and nasopharyngeal carcinoma $(47,48)$. EBV-persistent infection has been associated with oral cancers, even though there are few epidemiological data available (49).

\section{Epigenetics}

Epigenetics refers to changes in DNA expression not attributable to alterations in DNA sequence. The main events responsible are DNA methylation, histone modification and post-transcriptional gene downregulation by microRNAs (miRNA/miRs). These alterations can persist for a cell lifetime and be inherited by subsequent generations.

The results of epigenetics vary from increased gene expression to complete silencing, depending on the interference of these alterations to activators and suppressors of specific promoters in chromatin. Therefore, epigenetic changes can induce overexpression of oncogenes as much as silencing of tumor suppressor genes (50).

DNA methylation is the most common epigenetic event (51). It is performed by a series of enzymes known as DNA methyltransferases (DNMTs). These enzymes catalyze the covalent addition of a methyl group to the carbon-5 position of cytosine bases that are located $5^{\prime}$ to a guanosine base in a CpG dinucleotide (52).

Hypermethylation has been identified in the promoters of tumor suppressor genes in numerous cancers; this may lead to the reduction of their expression or to their complete silencing (49). Conversely, hypo/demethylation of the promoter of proto-oncogenes may lead to increased expression of these genes (50). An imbalance in tumor suppressor gene methylation status has often been reported following exposure to tobacco-derived carcinogens and other environmental compounds including cadmium, arsenic and nickel (52).

Many genes present an altered DNA methylation profile in OSCC and OPSCC (53). The galanin (GAL) gene maps onto chromosome 11q13.2, and is a neuropeptide widely distributed in the central and peripheral nervous system (54). It has the function of regulating anterior pituitary hormones secretion and acts as neurotransmitter (54). GALR1 and GALR2 are two of the three receptors for galanin; their genes are located on chromosome $18 \mathrm{q} 23$ and $17 \mathrm{q} 25.1$, respectively. These receptors are members of the $\mathrm{G}$ protein-coupled receptor (GPCR) superfamily. Galanin and its receptors regulate growth via the inhibition of extracellular signal-regulated kinase (ERK) $1 / 2$, upregulation of the cyclin-dependent kinase inhibitors p27 and p57, and decreased expression of cyclin D1, which can altogether limit cell proliferation (55). Additionally, GALR2 can induce caspase-3 dependent apoptosis (55-57). Hypermethylation of these genes leads to a lack of their expression with a consequent lack of their tumor suppressor activity (57). A previous study identified 25 out of 48 (52\%) OSCC cases to have hypermethylation of at least one of the three genes; furthermore in OPSCC, 13 out of 20 cases $(65 \%)$ were determined to have hypermethylation of at least one of the genes (58).

Calprotectin S100A8/9 is a heterodimer of the two calcium-binding proteins S100A8 and S100A9. S100A8/9 is located both within epithelial cells and in the extracellular space (59). In normal epithelial cells, S100A8/9 works to arrest the cell cycle by activating the G2/M DNA damage checkpoint (59); a function that has been evidenced in the TR146 cell line (an oral cancer-derived cell line) (60). In HNSCC, it has been identified that S100A8/9 level was on average 10-fold lower compared with in normal adjacent tissues (60). Additionally, S100A8/9 in the extracellular space is released from polymorphonuclear, leukocytes and macrophages and works by signaling through the receptor for advanced glycation end products and toll-like receptor (TLR) 4 (61).

Notably, it has been reported that S100A9 promoter hypermethylation correlates with reduced expression of S100A9. S100A8 expression, conversely, does not correlate with its promoter methylation (60).

\section{Saliva-detectable hypermethylation}

Saliva is an emerging diagnostic medium for oral and oropharyngeal cancers. It represents an effective diagnostic alternative since it is produced and collected close to the sites of malignancy; this provides the possibility to analyze tumor-specific biomolecules with minimal interferences (61). Additionally, saliva allows analysis of regions including the tonsillar crypts, which are otherwise difficult to sample (62). Ultimately, saliva sampling is easy to perform $(63,64)$.

Several hypermethylated genes have been detected via saliva sampling (Table I). Insulin-like growth factor (IGF)-binding protein 7 (IGFBP-7) is a protein involved in the regulation of free IGF concentration in tissues (65). It is also involved in tumor suppressor activity and in epithelial-mesenchymal transition (EMT) $(66,67)$. In a previous cohort of 47 oral tongue cancer cases, IGFBP-7 promoter was reportedly hypermethylated, and consequently, IGFBP-7 marginally expressed. Furthermore, hypermethylation in these cases was documented to correlate with invasive depth, locoregional recurrence and poor prognosis (67).

Krüppel-like factor 4 (KLF4) is a is a zinc-finger transcription factor encoded by a gene located on chromosome $9 q 31.2$. It is involved in epidermal barrier function (68), cell proliferation, differentiation and apoptosis (69) and stem cell renewal (70). The activity and expression of KLF4 are often associated with mutation in various cancers (71-74). Li et al (75), identified that KLF4 was downregulated in OSCC, and its downregulation correlated with cancer differentiation i.e., the poorer the cancer differentiation, the lower the 
Table I. List of genes found hypermethylated in saliva samples, their reported function and the tumor type where modifications were present.

\begin{tabular}{|c|c|c|c|c|}
\hline Gene & Gene product & Function & $\begin{array}{c}\text { Tumor site } \\
\text { (OSCC/OPSCC) }\end{array}$ & (Refs.) \\
\hline CCNA1 & Cyclin A1 & Cell cycle regulation & $\begin{array}{l}\text { OSCC and } \\
\text { OPSCC }\end{array}$ & $(62,99)$ \\
\hline DAPK1 & $\begin{array}{l}\text { Death-associated } \\
\text { protein kinase } 1\end{array}$ & Apoptosis and autophagy & $\begin{array}{l}\text { OSCC and } \\
\text { OPSCC }\end{array}$ & $(62,63,99)$ \\
\hline DCC & $\begin{array}{l}\text { Deleted in } \\
\text { colorectal carcinoma }\end{array}$ & Netrin 1 receptor & OSCC & $(62,100)$ \\
\hline EDNRB & Endothelin receptor type B & G protein-coupled receptor & OSCC & $(62,100)$ \\
\hline ERCC1 & $\begin{array}{l}\text { Excision repair } \\
\text { cross-complementation } \\
\text { group } 1\end{array}$ & $\begin{array}{l}\text { Repair of DNA damage } \\
\text { induced by ultraviolet light } \\
\text { or cisplatin }\end{array}$ & $\begin{array}{l}\text { OSCC and } \\
\text { OPSCC }\end{array}$ & $(62,101)$ \\
\hline HOXA9 & Homeobox protein Hox-A9 & $\begin{array}{l}\text { Gene expression, } \\
\text { morphogenesis } \\
\text { and differentiation }\end{array}$ & OSCC & $(62,101)$ \\
\hline KIF1A & Kinesin family member $1 \mathrm{~A}$ & $\begin{array}{l}\text { Membranous organelle } \\
\text { transportation along } \\
\text { axonal microtubules }\end{array}$ & OSCC & $(62,102,103)$ \\
\hline MED15 & $\begin{array}{l}\text { Mediator of RNA } \\
\text { polymerase II transcription } \\
\text { subunit } 15\end{array}$ & $\begin{array}{l}\text { Transcriptional coactivator } \\
\text { in RNA polymerase II } \\
\text { transcription }\end{array}$ & OSCC & $(62,104)$ \\
\hline MINT31 & $\begin{array}{l}\text { Spen family transcriptional } \\
\text { repressor family } \\
\text { transcriptional repressor }\end{array}$ & Calcium channel regulator & OSCC & $(62,99,105)$ \\
\hline NID2 & Nidogen-2 & Cell adhesion & OSCC & $(62,102)$ \\
\hline PAXI & Paxillin & $\begin{array}{l}\text { Cytoskeletal protein involved } \\
\text { in actin-membrane attachment } \\
\text { at sites of cell adhesion } \\
\text { to the extracellular matrix }\end{array}$ & OSCC & $(62,106)$ \\
\hline p16INK2A & $\begin{array}{l}\text { p16 (also known as } \\
\text { cyclin-dependent kinase } \\
\text { inhibitor } 2 \mathrm{~A} \text { ) }\end{array}$ & Tumor suppressor gene & OSCC & $(62,63,99)$ \\
\hline RASSF1 $\alpha$ & $\begin{array}{l}\text { Ras association domain } \\
\text { family member } 1 \alpha\end{array}$ & $\begin{array}{l}\text { Growth inhibition along the } \\
\text { RAS-activated signaling pathway }\end{array}$ & OSCC & $(62,63)$ \\
\hline TIMP3 & Metalloproteinase inhibitor 3 & $\begin{array}{l}\text { Inhibitor of the matrix } \\
\text { metalloproteinases }\end{array}$ & $\begin{array}{l}\text { OSCC and } \\
\text { OPSCC }\end{array}$ & $(62,99,105,107)$ \\
\hline
\end{tabular}

OSCC, oral squamous cell carcinoma; OPSCC, oropharyngeal squamous cell carcinoma.

expression of KLF. The downregulation of KLF4 in OSCC has been associated with promoter hypermethylation (75).

Somatostatin (SST) and somatostatin SST receptor type 1 (SSTR1) are encoded by genes located on 3q27.3 and $14 \mathrm{q} 21.1$, respectively. SST is a peptide hormone that exists in two forms (14 amino acids and 28 amino acids), both encoded by the same gene. SST has several functions: It inhibits growth hormone (GH) secretion; it works as an immunomodulator to cause an inhibition of tumor necrosis factor- $\alpha$, interferon- $\gamma$, corticotropin releasing hormone and substance $\mathrm{P}$ secretion; and it binds $\mu$-opioid receptor (76). Additionally, SST interacts with SSTR1 to cause an antiproliferative effect. In fact, the activity of SSTR1 may lead to the activation of SHP-2 (also known as tyrosine-protein phosphatase non-receptor type 11); SHP-2 dephosphorylates the proto-oncogene tyrosine-protein kinase c-src on Tyr529 (inhibitory site) and makes possible phosphorylation on Tyr418 (stimulatory site). Once activated, c-src may also phosphorylate Raf-1,the function of which is to activate (through phosphorylation) mitogen activated-protein kinase signaling, which can eventually lead to cell cycle inhibition through p21/Cip1. Besides these direct effects, SST and its receptors may inhibit proliferation through indirect effects. In fact, the activation of the SST pathway may cause a reduction of IGF-1 synthesis and inhibition of angiogenesis (77).

SSTR1 is one of the five receptors for SST, and an inhibitory GPCR (78). Misawa et al (79), have demonstrated SST 
Table II. List of miRNAs with altered expression, on saliva specimen testing, in oral and/or oropharyngeal cancers.

\begin{tabular}{|c|c|c|c|}
\hline Name & Status & Tumor type & (Refs.) \\
\hline miR-9 & Overexpressed & HPV-negative HNSCC & $(62)$ \\
\hline $\operatorname{miR}-24$ & Overexpressed & OSCC (vs. healthy controls) & $(62,108)$ \\
\hline $\operatorname{miR}-27 b$ & Overexpressed & OSCC (vs. healthy controls) & $(62,108)$ \\
\hline & & OSCC in remission & \\
\hline $\operatorname{miR}-31$ & Overexpressed & $\begin{array}{l}\text { HPV-related OSCC and OPSCC } \\
\text { (vs. healthy controls and leukoplakia) }\end{array}$ & $(62,109,110)$ \\
\hline $\operatorname{miR}-134$ & Overexpressed & HNSCC & $(62,111)$ \\
\hline miR-191 & Overexpressed & HNSCC & $(62,111)$ \\
\hline $\operatorname{miR}-125 \mathrm{a}$ & Underexpressed & OSCC & $(62,112)$ \\
\hline miR-136 & Underexpressed & OSCC (vs. healthy controls) & $(62,108)$ \\
\hline miR-147 & Underexpressed & OSCC (vs. healthy controls) & $(62,108)$ \\
\hline miR-148a & Underexpressed & OSCC (vs. healthy controls) & $(62,108)$ \\
\hline miR-200a & Underexpressed & OSCC (vs. control samples) & $(62,112,113)$ \\
\hline miR-222 & Underexpressed & OSCC and OPSCC & $(62,109)$ \\
\hline miR-323-5p & Underexpressed & OSCC (vs. healthy controls) & $(62,108)$ \\
\hline miR-503 & Underexpressed & OSCC (vs. healthy controls) & $(62,108)$ \\
\hline miR-622 & Underexpressed & OSCC (vs. healthy controls) & $(62,108)$ \\
\hline miR-646 & Underexpressed & OSCC (vs. healthy controls) & $(62,108)$ \\
\hline miR-668 & Underexpressed & OSCC (vs. healthy controls) & $(62,108)$ \\
\hline miR-877 & Underexpressed & OSCC (vs. healthy controls) & $(62,108)$ \\
\hline miR-1250 & Underexpressed & OSCC (vs. healthy controls) & $(62,108)$ \\
\hline
\end{tabular}

miRNA/miR, microRNA; OSCC, oral squamous cell carcinoma; OPSCC, oropharyngeal squamous cell carcinoma; HNSCC, head and neck squamous cell carcinoma; HPV, human papillomavirus.

and SSTR1 promoter hypermethylation in OSCC, OPSCC primary tumor samples and in UM-SCC cell lines; these findings suggest that SST and SSTR1 may be considered as important molecules in the tumorigenesis and progression of OSCC and OPSCC.

Other genes observed to be hypermethylated in saliva samples in oral/oropharyngeal cancers are listed in Table I.

\section{5. miRNA}

miRNAs represent a category of non-coding RNA molecules, each made of $\sim 22$ nucleotides. These molecules are involved in the control of gene expression by interacting with mRNA (80). miR-143 is a miRNA capable of interacting with the 3' untranslated region of hexokinase 2 (HK2) mRNA (81). Elevated concentrations of HK2 have been observed in numerous cancers, including oral and oropharyngeal cancers; in particular, it has been determined in OSCC-derived cell lines that there was a lower concentration of miR-143, compared with in normal keratinocytes and, consequently, higher concentrations of HK2, since miR-143 inhibits HK2 synthesis (81).

Saliva-detectable miRNA. Saliva may be sampled and analyzed for the identification of miRNAs. Several miRNAs have been identified to be overexpressed or underexpressed in patients with oral and/or oropharyngeal cancer. For instance, miR-491-5p is a miRNA that has been implicated in a number of important processes, including migration, invasion and consequently metastasis. The function of miR-491-5p is to target GPCR kinase-interacting protein 1 (GIT1), leading to a downregulation of its expression. A well-established function of GIT1 is to initiate cell motility; this is achieved through interactions with members of the focal adhesion kinase and ERK1/2 pathways.

Huang et al (82), reported that miR-491-5p was downregulated in highly aggressive OSCC cell lines (SAS-I5, OECM-1-I8, SCC25-I6, OC-3-I5- and OC-3-I5-lung-IV2) and in 29 out of 33 OSCC samples compared with in normal tissue. They also demonstrated that cells with low miR-491-5p expression exhibited enhanced capability to migrate and metastasize, and furthermore, that miR-491-5 low expression was correlated with poor prognosis (82).

Examples of miRNAs observed to be over- or underexpressed in OSCC/OPSCC are listed in Table II.

\section{Therapeutic implications}

To date, there are few chemotherapeutic options for oral and oropharyngeal cancers. Platinum-based antineoplastics are the most frequently used; however, their efficacy is not satisfactory $(83,84)$.

The biology of epigenetics can be used for therapeutic purposes; well known among such applications is in the context of viral mimicry. Viral mimicry refers to a characteristic behavior that certain cancer cells acquire when treated with demethylating agents; these treatments can lead to an effect that mimics a viral infection (85). The exact mechanism of action is not fully understood, nor is the reasoning behind 
why certain cells are more susceptible than others, or why in certain cases the efficacy of demethylating agents decreases over time $(85,86)$.

Viral mimicry is based on a series of immune effects on tumor cells. Demethylating agents may stimulate viral defense and type I interferon signaling; this effect can be achieved through RNA demethylation (85). In fact, demethylated RNA is known to stimulate an interferon response through TLR3 activation; a similar response to DNA demethylation is suggested to occur by a similar effect obtained using demethylating agents which target only DNA (85).

Another immune effect seen with demethylating agents involves double-stranded RNA (dsRNA). In fact, these drugs have been associated with an increase of cytosolic levels of dsRNA; dsRNA molecules are used by epithelial and other cells as a defense mechanism towards viral infection, which in turn may lead to a type I interferon response and apoptosis (85). Viral mimicry has been observed and studied in various cancers, including colon (86) and breast (87) cancers.

Another notable mechanism of action involves endogenous retroviral genes. These genes comprise $\sim 8 \%$ of the human genome and are normally silenced through hypermethylation in somatic cells (82). With demethylating drugs these genes are unlocked, and their RNA levels increase in the cell cytoplasm. This may then promote the activation of a viral defense response through RNA sensors (85).

Additionally, demethylating agents may cause toxicity in cancer cells through non-immune mechanisms of action. One of the most plausible and studied mechanisms of action is based on the evidence that cancerous cells share an overall hypermethylation of tumor-suppressor gene promoters; with demethylating agents, these genes are 'unlocked' and therefore can provide a tumor-suppressor function (86).

Gene-body methylation may also be important. It affects transcription in a directly proportional way, in that the more a gene-body is methylated, the more it is expressed $(86,88)$. However, this mechanism is poorly understood $(86,88)$.

Another theory is based on the evidence that global demethylation may lead to direct toxicity in cancerous cells, causing their death or interrupting their proliferation; normal cells instead tend to survive against these drugs $(86,89)$. However, the global DNA methylation state cannot predict response to therapy, and thus it is probably not the only mechanism involved (86).

Another mechanism of action describes the cytotoxicity of demethylating agents as the main cause of their efficacy in cancer therapy; specifically, they may trap DNMTs onto DNA, resulting in bulky adducts that can inhibit DNA synthesis and eventually cause cell death (86).

It is likely that all these theories have some involvement, though it is unknown which are more important than others.

5-Azacytidine (5-aza-CR) and 5-aza-2'-deoxycytidine are the main demethylating drugs. These are nucleoside analogs of cytosine and can inhibit DNA methylation by being incorporated in a DNA molecule at the position of cytosine during DNA replication (90). When a DNA methyltransferase interacts with a DNA molecule modified in this way, it ends adhere to the DNA, resulting in a long-lasting demethylation.
miRNA based therapy can be expected to be a critical topic in upcoming research. As discussed, miRNAs have a crucial role in regulating gene expression for both tumor suppressor genes and oncogenes. For therapeutic purposes, the aim is to inhibit the miRNAs that are overexpressed and to replace those that are insufficient.

Use of miRNA mimics is one such strategy to replace underexpressed miRNAs; these molecules must be modified to achieve optimal pharmacokinetics and pharmacodynamics, for example through conjugation with a sugar molecule or utilizing liposomes (91).

Conversely, treatment with miRNA inhibitors is the strategy for lowering the concentration of overexpressed miRNAs. These molecules are capable of binding specific miRNAs, preventing their binding with target mRNA (91).

\section{Conclusions}

Among the most considerable problems with treating OSCC and OPSCC is the tendency of these cancers to become chemo-radioresistant. However, this is among the issues that can be bypassed through epigenetic-based therapy; in fact, it is established that certain demethylase inhibitors can induce a chemo-radiotherapy resensitizing effect in various cancer types (92-94). HNSCC cell lines (including SQD9, SCC61, Cal27, SC179, SC263, JH011) have been identified to have an increased response to radiation therapy following exposure to demethylating agents in vitro $(95,96)$, suggesting that these drugs may be used efficiently in combination with other drugs and radiation to achieve an improved clinical outcome.

Another issue that may be, at least in part, bypassed with demethylating drugs is radiation-related toxicity; radiation therapy is associated with numerous side effects caused by direct effect of the radiation on healthy tissues $(97,98)$. In oral and oropharyngeal cancers, the most frequent of such effects are mucositis, dysphagia, trismus, dental problems, xerostomia and osteoradionecrosis $(97,98)$. As discussed, demethylating drugs may enhance the radiation sensibility of cancer cells; this would make possible the use of lower doses of radiation to achieve the same therapeutic benefits while potentially minimizing the side effects.

In conclusion, oral and oropharyngeal cancers represent a major health issue, both regarding their epidemiological characteristics and poor clinical outcome. There have been several advances in our understanding of these malignancies, some of which have been used for prevention purposes (for instance by acknowledging the risk factors), and others have had an impact on therapeutic approaches.

Epigenetics influences all phases of cancer development and progression. The understanding of its functioning comprises an important aim of recent research due to the possible therapeutic implications. This is particularly important in oral and oropharyngeal cancer, since the relevant therapeutic approaches and clinical outcomes are still based almost exclusively on classical chemotherapy. This is probably a main reason for the lack of improved survival outcome over time, or at least for the lower extent of improvement than would be expected. In the short term, it is probable that epigenetics will be used as a basis for therapeutic purposes. 


\section{Acknowledgements}

Not applicable.

\section{Funding}

No funding was received.

\section{Availability of data and materials}

Not applicable.

\section{Authors' contributions}

DR, FM, SS and GI designed and wrote the manuscript.SV, GS, GZ, RDC and VS performed the literature search; MM, $\mathrm{AC}, \mathrm{LC}$ revised the manuscript for intellectual content.

\section{Ethics approval and consent to participate}

Not applicable.

\section{Patient consent for publication}

Not applicable.

\section{Competing interests}

All authors declare no competing interests.

\section{References}

1. Torre LA, Bray F, Siegel RL, Ferlay J, Lortet-Tieulent J and Jemal A: Global cancer statistics, 2012. CA Cancer J Clin 65 87-108, 2015

2. Siegel RL, Miller KD and Jemal A: Cancer statistics, 2016. CA Cancer J Clin 66: 7-30, 2016.

3. Torre LA, Siegel RL, Ward EM and Jemal A: Global cancer incidence and mortality rates and trends - an update. Cancer Epidemiol Biomarkers Prev 25: 16-27, 2016.

4. Ferlay J, Soerjomataram I, Dikshit R, Eser S, Mathers C, Rebelo M, Parkin DM, Forman D and Bray F: Cancer incidence and mortality worldwide: Sources, methods and major patterns in GLOBOCAN 2012. Int J Cancer 136: E359-E386, 2015.

5. Warnakulasuriya S: Global epidemiology of oral and oropharyngeal cancer. Oral Oncol 45: 309-316, 2009.

6. Gupta B, Johnson NW and Kumar N: Global epidemiology of head and neck cancers: A continuing challenge. Oncology 91: 13-23, 2016

7. Mydlarz WK, Hennessey PT and Califano JA: Advances and perspectives in the molecular diagnosis of head and neck cancer. Expert Opin Med Diagn 4: 53-65, 2010.

8. Argiris A, Karamouzis MV, Raben D and Ferris RL: Head and neck cancer. Lancet 371: 1695-1709, 2008.

9. Leemans CR, Braakhuis BJM and Brakenhoff RH: The molecular biology of head and neck cancer. Nat Rev Cancer 11: 9-22, 2011.

10. Chaturvedi AK, Engels EA, Anderson WF and Gillison ML: Incidence trends for human papillomavirus-related and -unrelated oral squamous cell carcinomas in the United States. J Clin Oncol 26: 612-619, 2008.

11. Ang KK, Harris J, Wheeler R, Weber R, Rosenthal DI, Nguyen-Tân PF, Westra WH, Chung CH, Jordan RC, Lu C, et al: Human papillomavirus and survival of patients with oropharyngeal cancer. N Engl J Med 363: 24-35, 2010.

12. Slaughter DP, Southwick HW and Smejkal W: Field cancerization in oral stratified squamous epithelium; clinical implications of multicentric origin. Cancer 6: 963-968, 1953.

13. Tabor MP, Brakenhoff RH, Ruijter-Schippers HJ, Kummer JA, Leemans CR and Braakhuis BJM: Genetically altered fields as origin of locally recurrent head and neck cancer: A retrospective study. Clin Cancer Res 10: 3607-3613, 2004.
14. Prevo LJ, Sanchez CA, Galipeau PC and Reid BJ: p53-mutant clones and field effects in Barrett's esophagus. Cancer Res 59: 4784-4787, 1999.

15. Hawthorn L, Lan L and Mojica W: Evidence for field effect cancerization in colorectal cancer. Genomics 103: 211-221, 2014.

16. Jones TD, Wang M, Eble JN, MacLennan GT, Lopez-Beltran A, Zhang S, Cocco A and Cheng L: Molecular evidence supporting field effect in urothelial carcinogenesis. Clin Cancer Res 11: 6512-6519, 2005.

17. Torezan LAR and Festa-Neto C: Cutaneous field cancerization: Clinical, histopathological and therapeutic aspects. An Bras Dermatol 88: 775-786, 2013.

18. Rivenbark AG and Coleman WB: Field cancerization in mammary carcinogenesis - Implications for prevention and treatment of breast cancer. Exp Mol Pathol 93: 391-398, 2012

19. Chu TY, Shen CY, Lee HS and Liu HS: Monoclonality and surface lesion-specific microsatellite alterations in premalignant and malignant neoplasia of uterine cervix: A local field effect of genomic instability and clonal evolution. Genes Chromosomes Cancer 24: 127-134, 1999.

20. Gomperts BN, Spira A, Massion PP, Walser TC, Wistuba II, Minna JD and Dubinett SM: Evolving concepts in lung carcinogenesis. Semin Respir Crit Care Med 32: 32-43, 2011.

21. Kreimer AR, Clifford GM, Boyle P and Franceschi S: Human papillomavirus types in head and neck squamous cell carcinomas worldwide: A systematic review. Cancer Epidemiol Biomarkers Prev 14: 467-475, 2005

22. Hannisdal K, Schjølberg A, De Angelis PM, Boysen M and Clausen OPF: Human papillomavirus (HPV)-positive tonsillar carcinomas are frequent and have a favourable prognosis in males in Norway. Acta Otolaryngol 130: 293-299, 2010.

23. Attner $\mathrm{P}, \mathrm{Du}$ J, Näsman A, Hammarstedt L, Ramqvist $\mathrm{T}$, Lindholm J, Marklund L, Dalianis T and Munck-Wikland E: The role of human papillomavirus in the increased incidence of base of tongue cancer. Int J Cancer 126: 2879-2884, 2010.

24. Ramqvist T, Grün N and Dalianis T: Human papillomavirus and tonsillar and base of tongue cancer. Viruses 7: 1332-1343, 2015.

25. Ghittoni R, Accardi R, Hasan U, Gheit T, Sylla B and Tommasino M: The biological properties of E6 and E7 oncoproteins from human papillomaviruses. Virus Genes 40: 1-13, 2010.

26. Huibregtse JM, Scheffner M and Howley PM: A cellular protein mediates association of $\mathrm{p} 53$ with the E6 oncoprotein of human papillomavirus types 16 or 18. EMBO J 10: 4129-4135, 1991.

27. Scheffner M, Huibregtse JM, Vierstra RD and Howley PM: The HPV-16 E6 and E6-AP complex functions as a ubiquitin-protein ligase in the ubiquitination of p53. Cell 75: 495-505, 1993.

28. Mascolo M, Ilardi G, Romano MF, Celetti A, Siano M, Romano S, Luise C, Merolla F, Rocco A, Vecchione ML, et al: Overexpression of chromatin assembly factor-1 p60, poly(ADP-ribose) polymerase 1 and nestin predicts metastasizing behaviour of oral cancer. Histopathology 61: 1089-1105, 2012.

29. Aquino G, Pannone G, Santoro A, Liguori G, Franco R, Serpico R, Florio G, de Rosa A, Mattoni M, Cozza V, et al: pEGFR-Tyr 845 expression as prognostic factors in oral squamous cell carcinoma: A tissue-microarray study with clinic-pathological correlations. Cancer Biol Ther 13: 967-977, 2012.

30. Pannone G, Rodolico V, Santoro A, Lo Muzio L, Franco R, Botti G, Aquino G, Pedicillo MC, Cagiano S, Campisi G, et al: Evaluation of a combined triple method to detect causative HPV in oral and oropharyngeal squamous cell carcinomas: p16 Immunohistochemistry, Consensus PCR HPV-DNA, and In Situ Hybridization. Infect Agent Cancer 7: 4, 2012.

31. Santoro A, Pannone G, Papagerakis S, McGuff HS, Cafarelli B, Lepore S, De Maria S, Rubini C, Mattoni M, Staibano S, et al: Beta-catenin and epithelial tumors: A study based on 374 oropharyngeal cancers. BioMed Res Int 2014: 948264, 2014.

32. Russo D, Merolla F, Mascolo M, Ilardi G, Romano S, Varricchio S, Napolitano V, Celetti A, Postiglione L, Di Lorenzo PP, et al: FKBP51 immunohistochemical expression: A new prognostic biomarker for OSCC? Int J Mol Sci 18: 443, 2017.

33. Mascolo M, Ilardi G, Merolla F, Russo D, Vecchione ML, de Rosa G and Staibano S: Tissue microarray-based evaluation of Chromatin Assembly Factor-1 (CAF-1)/p60 as tumour prognostic marker. Int J Mol Sci 13: 11044-11062, 2012.

34. Lo Muzio L, Campisi G, Giovannelli L, Ammatuna P, Greco I, Staibano S, Pannone G, De Rosa G, Di Liberto C and D'Angelo M: HPV DNA and survivin expression in epithelial oral carcinogenesis: A relationship? Oral Oncol 40: 736-741, 2004. 
35. Weinberger PM, Yu Z, Kountourakis P, Sasaki C, Haffty BG, Kowalski D, Merkley MA, Rimm DL, Camp RL and Psyrri A: Defining molecular phenotypes of human papillomavirus-associated oropharyngeal squamous cell carcinoma: Validation of three-class hypothesis. Otolaryngol Head Neck Surg 141: 382-389, 2009.

36. Jung AC, Briolat J, Millon R, de Reyniès A, Rickman D, Thomas E, Abecassis J, Clavel C and Wasylyk B: Biological and clinical relevance of transcriptionally active human papillomavirus (HPV) infection in oropharynx squamous cell carcinoma. Int J Cancer 126: 1882-1894, 2010.

37. Tomar S, Graves CA, Altomare D, Kowli S, Kassler S, Sutkowski N, Gillespie MB, Creek KE and Pirisi L: Human papillomavirus status and gene expression profiles of oropharyngeal and oral cancers from European American and African American patients. Head Neck 38 (Suppl 1): e694-e704, 2016.

38. Johannsen E and Lambert PF: Epigenetics of human papillomaviruses. Virology 445: 205-212, 2013.

39. Gameiro SF, Kolendowski B, Zhang A, Barrett JW, Nichols AC, Torchia J and Mymryk JS: Human papillomavirus dysregulates the cellular apparatus controlling the methylation status of H3K 27 in different human cancers to consistently alter gene expression regardless of tissue of origin. Oncotarget 8: 72564-72576, 2017.

40. Gupta PC, Murti PR, Bhonsle RB, Mehta FS and Pindborg JJ: Effect of cessation of tobacco use on the incidence of oral mucosal lesions in a $10 \mathrm{yr}$ follow-up study of 12,212 users. Oral Dis 1: 54-58, 1995.

41. Saman DM: A review of the epidemiology of oral and pharyngeal carcinoma: Update. Head Neck Oncol 4: 1, 2012.

42. Gandini S, Botteri E, Iodice S, Boniol M, Lowenfels AB, Maisonneuve P and Boyle P: Tobacco smoking and cancer: A meta-analysis. Int J Cancer 122: 155-164, 2008.

43. Marron M, Boffetta P, Zhang Z-F, Zaridze D, Wünsch-Filho V, Winn DM, Wei Q, Talamini R, Szeszenia-Dabrowska N, Sturgis EM, et al: Cessation of alcohol drinking, tobacco smoking and the reversal of head and neck cancer risk. Int J Epidemiol 39: 182-196, 2010

44. Mahapatra S, Kamath R, Shetty BK and Binu VS: Risk of oral cancer associated with gutka and other tobacco products: A hospital-based case-control study. J Cancer Res Ther 11: 199-203, 2015.

45. Reidy J, McHugh E and Stassen LFA: A review of the relationship between alcohol and oral cancer. Surgeon 9: 278-283, 2011.

46. Epstein MA, Achong BG and Barr YM: Virus particles in cultured lymphoblasts from burkitt's lymphoma. Lancet 1 : 702-703, 1964

47. IARC (International Agency for Research on Cancer): Epstein-Barr virus. A review o. (IARC (ed). Lyon, 2012

48. Prabhu SR and Wilson DF: Evidence of Epstein-Barr virus association with head and neck cancers: a review. J Can Dent Assoc 82: g2, 2016.

49. Higa M, Kinjo T, Kamiyama K, Iwamasa T, Hamada T and Iyama K: Epstein-Barr virus (EBV) subtype in EBV related oral squamous cell carcinoma in Okinawa, a subtropical island in southern Japan, compared with Kitakyushu and Kumamoto in mainland Japan. J Clin Pathol 55: 414-423, 2002.

50. Dawson MA and Kouzarides T: Cancer epigenetics: From mechanism to therapy. Cell 150: 12-27, 2012

51. Jones PA and Baylin SB: The fundamental role of epigenetic events in cancer. Nat Rev Genet 3: 415-428, 2002.

52. Hema KN, Smitha T, Sheethal HS and Mirnalini SA: Epigenetics in oral squamous cell carcinoma. J Oral Maxillofac Pathol 21 252-259, 2017.

53. Mascolo M, Siano M, Ilardi G, Russo D, Merolla F, De Rosa G and Staibano S: Epigenetic disregulation in oral cancer. Int J Mol Sci 13: 2331-2353, 2012

54. Mitsukawa K, Lu X and Bartfai T: Galanin, galanin receptors and drug targets. Cell Mol Life Sci 65: 1796-1805, 2008.

55. Kanazawa T, Misawa K and Carey TE: Galanin receptor subtypes 1 and 2 as therapeutic targets in head and neck squamous cell carcinoma. Expert Opin Ther Targets 14: 289-302, 2010.

56. Kanazawa T, Iwashita T, Kommareddi P, Nair T, Misawa K, Misawa Y, Ueda Y, Tono T and Carey TE: Galanin and galanin receptor type 1 suppress proliferation in squamous carcinoma cells: Activation of the extracellular signal regulated kinase pathway and induction of cyclin-dependent kinase inhibitors. Oncogene 26: 5762-5771, 2007

57. Kanazawa T, Kommareddi PK, Iwashita T, Kumar B, Misawa K, Misawa Y, Jang I, Nair TS, Iino Y and Carey TE: Galanin receptor subtype 2 suppresses cell proliferation and induces apoptosis in p53 mutant head and neck cancer cells. Clin Cancer Res 15: 2222-2230, 2009.
58. Misawa K, Misawa Y, Kanazawa T, Mochizuki D, Imai A, Endo S, Carey TE and Mineta H: Epigenetic inactivation of galanin and GALR1/2 is associated with early recurrence in head and neck cancer. Clin Exp Metastasis 33: 187-195, 2016

59. Khammanivong A, Wang C, Sorenson BS, Ross KF and Herzberg MC: S100A8/A9 (calprotectin) negatively regulates $\mathrm{G} 2 / \mathrm{M}$ cell cycle progression and growth of squamous cell carcinoma. PLoS One 8: e69395, 2013.

60. Khammanivong A, Sorenson BS, Ross KF, Dickerson EB, Hasina R, Lingen MW and Herzberg MC: Involvement of calprotectin (S100A8/A9) in molecular pathways associated with HNSCC. Oncotarget 7: 14029-14047, 2016.

61. Hessian PA and Fisher L: The heterodimeric complex of MRP-8 (S100A8) and MRP-14 (S100A9). Antibody recognition, epitope definition and the implications for structure. Eur J Biochem 268: 353-363, 2001.

62. Lim Y, Sun CX, Tran P and Punyadeera C: Salivary epigenetic biomarkers in head and neck squamous cell carcinomas. Biomarkers Med 10: 301-313, 2016.

63. Ovchinnikov DA, Cooper MA, Pandit P, Coman WB Cooper-White JJ, Keith P, Wolvetang EJ, Slowey PD and Punyadeera C: Tumor-suppressor Gene Promoter Hypermethylation in Saliva of Head and Neck Cancer Patients. Transl Oncol 5: 321-326, 2012.

64. Pfaffe T, Cooper-White J, Beyerlein P, Kostner K and Punyadeera C: Diagnostic potential of saliva: Current state and future applications. Clin Chem 57: 675-687, 2011.

65. Collet $\mathrm{C}$ and Candy J: How many insulin-like growth factor binding proteins? Mol Cell Endocrinol 139: 1-6, 1998.

66. Chen Y, Cui T, Knösel T, Yang L, Zöller K and Petersen I: IGFBP7 is a p53 target gene inactivated in human lung cancer by DNA hypermethylation. Lung Cancer 73: 38-44, 2011.

67. Chen LH, Liu DW, Chang JL, Chen PR, Hsu LP, Lin HY, Chou YF, Lee CF, Yang MC, Wen YH, et al: Methylation status of insulin-like growth factor-binding protein 7 concurs with the malignance of oral tongue cancer. J Exp Clin Cancer Res 34: 20 , 2015.

68. Segre JA, Bauer C and Fuchs E: Klf4 is a transcription factor required for establishing the barrier function of the skin. Nat Genet 22: 356-360, 1999.

69. Feinberg MW, Wara AK, Cao Z, Lebedeva MA, Rosenbauer F, Iwasaki H, Hirai H, Katz JP, Haspel RL, Gray S, et al: The Kruppel-like factor KLF4 is a critical regulator of monocyte differentiation. EMBO J 26: 4138-4148, 2007.

70. Schmidt R and Plath K: The roles of the reprogramming factors Oct4, Sox 2 and Klf4 in resetting the somatic cell epigenome during induced pluripotent stem cell generation. Genome Biol 13: $251,2012$.

71. Wei D, Gong W, Kanai M, Schlunk C, Wang L, Yao JC, Wu TT, Huang S and Xie K: Drastic down-regulation of Krüppel-like factor 4 expression is critical in human gastric cancer development and progression. Cancer Res 65: 2746-2754, 2005.

72. Le Magnen C, Bubendorf L, Ruiz C, Zlobec I, Bachmann A, Heberer M, Spagnoli GC, Wyler S and Mengus C: Klf4 transcription factor is expressed in the cytoplasm of prostate cancer cells. Eur J Cancer 49: 955-963, 2013.

73. Naranjo Gómez JM, Bernal JFV, Arranz PG, Fernández SL and Roman JJG: Alterations in the expression of p53, KLF4, and p21 in neuroendocrine lung tumors. Arch Pathol Lab Med 138: 936-942, 2014

74. Ohnishi S, Ohnami S, Laub F, Aoki K, Suzuki K, Kanai Y, Haga K, Asaka M, Ramirez F and Yoshida T: Downregulation and growth inhibitory effect of epithelial-type Krüppel-like transcription factor KLF4, but not KLF5, in bladder cancer. Biochem Biophys Res Commun 308: 251-256, 2003.

75. Li W, Liu M, Su Y, Zhou X, Liu Y and Zhang X: The Janus-faced roles of Krüppel-like factor 4 in oral squamous cell carcinoma cells. Oncotarget 6: 44480-44494, 2015 .

76. Guillemin R: Hypothalamic hormones a.k.a. hypothalamic releasing factors. J Endocrinol 184: 11-28, 2005.

77. Theodoropoulou M and Stalla GK: Somatostatin receptors: From signaling to clinical practice. Front Neuroendocrinol 34: 228-252, 2013.

78. Lamberts SW, van der Lely AJ, de Herder WW and Hofland LJ: Octreotide. N Engl J Med 334: 246-254, 1996.

79. Misawa K, Misawa Y, Kondo H, Mochizuki D, Imai A, Fukushima H, Uehara T, Kanazawa T and Mineta H: Aberrant methylation inactivates somatostatin and somatostatin receptor type 1 in head and neck squamous cell carcinoma. PLoS One 10: e0118588, 2015. 
80. Esquela-Kerscher A and Slack FJ: Oncomirs - microRNAs with a role in cancer. Nat Rev Cancer 6: 259-269, 2006.

81. Peschiaroli A, Giacobbe A, Formosa A, Markert EK, Bongiorno-Borbone L, Levine AJ, Candi E, D'Alessandro A, Zolla L, Finazzi Agrò A, et al: miR-143 regulates hexokinase 2 expression in cancer cells. Oncogene 32: 797-802, 2013.

82. Huang WC, Chan SH, Jang TH, Chang JW, Ko YC, Yen TC, Chiang SL, Chiang WF, Shieh TY, Liao CT, et al: miRNA-491-5p and GIT1 serve as modulators and biomarkers for oral squamous cell carcinoma invasion and metastasis. Cancer Res 74: 751-764, 2014.

83. Alterio D, Bacigalupo A, Cantù G, et al: Linee guida - Tumori della testa e del collo. Aiom, Milano 2016 (In Italian).

84. Colevas AD, Yom SS, Pfister DG, Spencer S, Adelstein D, Adkins D, Brizel DM, Burtness B, Busse PM, Caudell JJ, et al: Head and neck cancers, version 1.2018. J Natl Compr Canc Netw 16: 479-490, 2018.

85. Chiappinelli KB, Strissel PL, Desrichard A, Li H, Henke C, Akman B, Hein A, Rote NS, Cope LM, Snyder A, et al: Inhibiting DNA methylation causes an interferon response in cancer via dsRNA including endogenous retroviruses. Cell 162: 974-986, 2015.

86. Roulois D, Loo Yau H, Singhania R, Wang Y, Danesh A, Shen SY, Han H, Liang G, Jones PA, Pugh TJ, et al: DNA-demethylating agents target colorectal cancer cells by inducing viral mimicry by endogenous transcripts. Cell 162: 961-973, 2015.

87. Nabet BY, Qiu Y, Shabason JE, Wu TJ, Yoon T, Kim BC, Benci JL, DeMichele AM, Tchou J, Marcotrigiano J, et al: Exosome RNA unshielding couples stromal activation to pattern recognition receptor signaling in cancer. Cell 170: 352-366.e13, 2017.

88. Yang X, Han H, De Carvalho DD, Lay FD, Jones PA and Liang G: Gene body methylation can alter gene expression and is a therapeutic target in cancer. Cancer Cell 26: 577-590, 2014.

89. Jones PA, Issa J-PJ and Baylin S: Targeting the cancer epigenome for therapy. Nat Rev Genet 17: 630-641, 2016.

90. Mani S and Herceg Z: DNA demethylating agents and epigenetic therapy of cancer. Adv Genet 70: 327-340, 2010.

91. Hammond SM: An overview of microRNAs. Adv Drug Deliv Rev 87: 3-14, 2015.

92. Li Y, Geng P, Jiang W, Wang Y, Yao J, Lin X, Liu J, Huang L, Su B and Chen $\mathrm{H}$ : Enhancement of radiosensitivity by 5 -Aza-CdR through activation of $\mathrm{G} 2 / \mathrm{M}$ checkpoint response and apoptosis in osteosarcoma cells. Tumour Biol 35: 4831-4839, 2014.

93. Festuccia C, Gravina GL, D'Alessandro AM, Muzi P Millimaggi D, Dolo V, Ricevuto E, Vicentini C and Bologna M: Azacitidine improves antitumor effects of docetaxel and cisplatin in aggressive prostate cancer models. Endocr Relat Cancer 16: 401-413, 2009.

94. Qiu H, Yashiro M, Shinto O, Matsuzaki T and Hirakawa K DNA methyltransferase inhibitor 5-aza-CdR enhances the radiosensitivity of gastric cancer cells. Cancer Sci 100: 181-188, 2009.

95. Brieger J, Mann SA, Pongsapich W, Koutsimpelas D, Fruth K and Mann WJ: Pharmacological genome demethylation increases radiosensitivity of head and neck squamous carcinoma cells. Int J Mol Med 29: 505-509, 2012.

96. De Schutter H, Kimpe M, Isebaert S and Nuyts S: A systematic assessment of radiation dose enhancement by 5-Aza-2'-deoxycytidine and histone deacetylase inhibitors in head-and-neck squamous cell carcinoma. Int J Radiat Oncol Biol Phys 73: 904-912, 2009.

97. Huang S-H and O'Sullivan B: Oral cancer: Current role of radiotherapy and chemotherapy. Med Oral Patol Oral Cir Bucal 18: e233-e240, 2013

98. Basu T, Laskar SG, Gupta T, Budrukkar A, Murthy V and Agarwal JP: Toxicity with radiotherapy for oral cancers and its management: A practical approach. J Cancer Res Ther 8 (Suppl 1): S72-S84, 2012
99. Sun W, Zaboli D, Liu Y, Arnaoutakis D, Khan T, Wang H, Koch W, Khan Z and Califano JA: Comparison of promoter hypermethylation pattern in salivary rinses collected with and without an exfoliating brush from patients with HNSCC. PLoS One 7: e33642, 2012.

100. Schussel J, Zhou XC, Zhang Z, Pattani K, Bermudez F, Jean-Charles G, McCaffrey T, Padhya T, Phelan J, Spivakovsky S, et al: EDNRB and DCC salivary rinse hypermethylation has a similar performance as expert clinical examination in discrimination of oral cancer/dysplasia versus benign lesions. Clin Cancer Res 19: 3268-3275, 2013.

101.Lima LMC, de Souza LR, da Silva TF, Pereira CS, Guimarães ALS, de Paula AMB and de Andrade Carvalho H: DNA repair gene excision repair cross complementing-group 1 (ERCC1) in head and neck squamous cell carcinoma: Analysis of methylation and polymorphism (G19007A), protein expression and association with epidemiological and clinicopathological factors. Histopathology 60: 489-496, 2012.

102. Guerrero-Preston R, Soudry E, Acero J, Orera M, Moreno-López L, Macía-Colón G, Jaffe A, Berdasco M, Ili-Gangas C, Brebi-Mieville P, et al: NID2 and HOXA9 promoter hypermethylation as biomarkers for prevention and early detection in oral cavity squamous cell carcinoma tissues and saliva. Cancer Prev Res (Phila) 4: 1061-1072, 2011.

103. Demokan S, Chang X, Chuang A, Mydlarz WK, Kaur J, Huang P, Khan Z, Khan T, Ostrow KL, Brait M, et al: KIF1A and EDNRB are differentially methylated in primary HNSCC and salivary rinses. Int J Cancer 127: 2351-2359, 2010.

104. Ovchinnikov DA, Wan Y, Coman WB, Pandit P, Cooper-White JJ, Herman JG and Punyadeera C: DNA Methylation at the Novel $\mathrm{CpG}$ Sites in the Promoter of MED15/PCQAP Gene as a Biomarker for Head and Neck Cancers. Biomark Insight 9: 53-60, 2014.

105. Sun W, Zaboli D, Wang H, Liu Y, Arnaoutakis D, Khan T, Khan Z, Koch WM and Califano JA: Detection of TIMP3 promoter hypermethylation in salivary rinse as an independent predictor of local recurrence-free survival in head and neck cancer. Clin Cancer Res 18: 1082-1091, 2012.

106. Huang YK, Peng BY, Wu CY, Su CT, Wang HC and Lai HC: DNA methylation of PAX1 as a biomarker for oral squamous cell carcinoma. Clin Oral Investig 18: 801-808, 2014

107. Rettori MM, de Carvalho AC, Bomfim Longo AL, de Oliveira CZ, Kowalski LP, Carvalho AL and Vettore AL: Prognostic significance of TIMP3 hypermethylation in post-treatment salivary rinse from head and neck squamous cell carcinoma patients. Carcinogenesis 34: 20-27, 2013.

108. Momen-Heravi F, Trachtenberg AJ, Kuo WP and Cheng YS: Genomewide Study of Salivary MicroRNAs for Detection of Oral Cancer. J Dent Res 93 (Suppl): 86S-93S, 2014.

109. Salazar C, Calvopiña D and Punyadeera C: miRNAs in human papilloma virus associated oral and oropharyngeal squamous cell carcinomas. Expert Rev Mol Diagn 14: 1033-1040, 2014

110. Liu CJ, Lin SC, Yang CC, Cheng HW and Chang KW: Exploiting salivary miR-31 as a clinical biomarker of oral squamous cell carcinoma. Head Neck 34: 219-224, 2012.

111. Salazar C, Nagadia R, Pandit P, Cooper-White J, Banerjee N, Dimitrova N, Coman WB and Punyadeera C: A novel saliva-based microRNA biomarker panel to detect head and neck cancers. Cell Oncol (Dordr) 37: 331-338, 2014

112. Park NJ, Zhou H, Elashoff D, Henson BS, Kastratovic DA, Abemayor E and Wong DT: Salivary microRNA: Discovery, characterization, and clinical utility for oral cancer detection. Clin Cancer Res 15: 5473-5477, 2009.

113. Wiklund ED, Gao S, Hulf T, Sibbritt T, Nair S, Costea DE, Villadsen SB, Bakholdt V, Bramsen JB, Sørensen JA, et al: MicroRNA alterations and associated aberrant DNA methylation patterns across multiple sample types in oral squamous cell carcinoma. PLoS One 6: e27840, 2011. 